\title{
EFISIENSI PENGGUNAAN TELUR DALAM PEMBUATAN SPONGE CAKE
}

\author{
Oleh \\ Ida Ayu Putu Hemy Ekayani \\ Jurusan Pendidikan Kesejahteraan dan Keluarga, FTK, UNDIKSHA
}

\begin{abstract}
ABSTRAK
Penelitian ini bertujuan untuk membuat kue berpori (spong cake) dengan kualitas baik dengan menggunakan jumlah telur minimal yang dibantu dengan penggunaan baking powder secara optimal untuk menurunkan biaya produksi yang disebabkan oleh mahalnya harga telur. Penelitian ini merupakan penelitian laboratorium (eksperimen). Analisis data dilakukan secara deskriptif. Hasil penelitian menunjukkan bahwa kualitas sponge cake terbaik dihasilkan dari dua variasi rancangan variasi kadar baking powder dan telur yakni resep pertama dengan formulasi tepung terigu 100 gram, baking powder 6 gram, telur 100 gram, lemak 75 gram, dan tanpa penambahaan air; dan resep ke dua dengan formulasi tepung terigu 100 gram, baking powder 2 gram, telur 80 gram, lemak 75 gram, dan air 16 gram. Jumlah telur yang digunakaan dalam kedua resep tersebut cukup jauh berkurang dari resep umum yang menggunakan 180 gram telur untuk 100 gram tepung terigu. Temuan penelitian ini akan berimplikasi pada sponge cake dengan harga yang lebih murah, tetapi dengan kualitas yang tetap relatif baik dapat dihadirkan ke pasar.
\end{abstract}

Kata-kata kunci: spong cake, kualitas, baking powder, biaya produksi

\begin{abstract}
This experimental research proposed to find a formula (recipe) of sponge cake making with good quality with minimal use of expensive egg and substituted the egg function by baking powder to reduce production cost. Research data were qualitatively analyzed. The research found two recipes that can reduce the production cost namely recipe 1 with the formula of 100 gram wheat flour, 6 gram baking powder, 100 gram egg, 75 gram margarine, and without water addition; and recipe 2 with the formula of 100 gram wheat flour, 2 gram baking powder, 80 gram egg, 75 gram margarine, and water addition of 16 gram. The amounts off egg used in both recipes are lower than the common recipe using 180 gram egg for the 100 gram of wheat flour. The research finding imply that cheaper sponge cake with relatively remain good quality can be introduced into the market.
\end{abstract}

Key words: spong cake, quiality, baking powder, production cost. 


\section{PENDAHULUAN}

Cake merupakan jenis kue modern yang banyak disukai karena rasanya yang manis, tampilan menarik, dan bercita rasa tinggi. Berbagai jenis cake telah banyak dikenal, bahkan hampir di setiap acara (seminar, rapat, hajatan, dan upacara keagamaan) jenis kue ini menjadi pilihan hidangan, karena selain rasanya yang enak dan bertekstur lembut juga dapat disimpan dalam waktu yang lebih lama dibandingkan dengan kue-kue tradisional. Cake merupakan suatu adonan lembut yang terdiri dari tepung, gula, lemak, telur yang teknik penyelesaian dengan cara dioven.

Cake dapat dibuat dengan berbagai variasi baik dari segi bentuk, bahan isi maupun penyajiannya. Formulasi yang tepat akan menghasilkan cake yang baik, hal ini tergantung bahan-bahan, komposisi yang digunakan dalam membuatnya, cara mengocok hingga cara memasaknya. Dari hasil pengamatan dan pengalaman peneliti sebagai penggemar cake, hanya sedikit cake yang dijual mempunyai kualitas yang cukup baik yakni rasa manis, dan menarik. Daya tarik kue juga penting. Kue yang menarik umumnya memiliki warna cerah (bloom), volume tidak terlalu besar/tidak terlalu kecil, tekstur lembut dan halus, beraroma sedap dan dapat membangkitkan selera (Nova, 1992). Sebagian besar cake yang dijual memiliki tekstur keras, kasar, beremah, warna pucat, dan kurang beraroma. Hal ini dapat disebabkan oleh beberapa faktor seperti komposisi bahan yang kurang tepat, takaran yang keliru, salah mengawinkan bahan yang satu dengan yang lain, walaupun prosedur yang digunakan sudah tepat.

Keberhasilan dalam membuat cake yang baik bukan hanya tergantung dari resep, pemahaman terhadap fungsi tiap bahan pada kue sangat berperan untuk menghindari kegagalan dalam pembuatan cake. Tiap resep yang ditawarkan belum menjamin akan menghasilkan kue yang baik, hal ini berdasarkan pengalaman peneliti yang hampir 12 tahun menjadi tenaga pengajar dibidang boga. Tepung terigu yang berfungsi untuk membangun kerangka kue, mengikat bahan lain untuk menghasilkan remah/tekstur kue. Gula bukan hanya pemberi rasa manis juga dapat memberi warna pada kerak kue, mengempukkan kue, melembabkan dan melemaskan adonan. Lemak dalam kue untuk memberi daya tahan, menambah nilai 
gizi, memberi aroma, mengempukkan dan memberi rasa gurih. Telur yang merupakan bahan utama dalam pembuatan cake memiliki kegunaan membangun kerangka cake, mewarnai cake, memberi nilai gizi dan melembabkan kue (Nova, 1992). Ada pendapat yang menyatakan kalau kue mau enak telurnya harus banyak. Pendapat ini tidak sepenuhnya benar, telur yang lebih banyak dari tepung menyebabkan cake mengkerut (ketebalan turun) pada waktu dikeluarkan dari oven. Di samping itu, penambahan jumlah telur membuat kue menjadi mahal yang biasanya menjadi permasalahan pengusaha kue.

Bahan tambahan sejenis baking soda (soda kue atau baking powder) dapat membantu mengembangkan kue, dimana penggunaannya disesuaikan dengan jenis kue yang akan dibuat. Pemakaian baking soda ini memiliki keuntungan yakni dapat mengurangi penggunaan jumlah telur. Dalam pembuatan cake, telur yang diperlukan cukup banyak (baik putih maupun kuning telur). Harga telur cenderung mahal, sehingga membuat harga cake juga semakin mahal. Hal ini tentu menyulitkan dalam hal penjualan (pemasaran cake), apalagi daya beli masyarakat yang cukup rendah. Untuk itulah solusi yang dilakukan dengan menambahkan baking powder ke dalam adonan cake tentunya dengan takaran yang tepat. Penambahan baking soda ke dalam adonan kue selain lebih ekonomis, juga berfungsi sebagai penstabil adonan kue sekaligus meningkatkan volume adonan selama proses pengopenan (pemanasan). Pemakaian baking soda yang berlebihan menyebabkan kue tidak enak disantap (kue terasa pahit), untuk itu perlu diketahui formulasi yang tepat dalam penggunaannya.

Sementara ini kue cake yang bermutu harganya mahal dan kurang terjangkau masyarakat umum. Teknologi pengolahan pangan secara efektif dan efisien masih sangat diperlukan di Indonesia, terutama dalam meningkatkan nilai tambah bahan, tetapi tetap memperhatikan mutu produk. Upaya-upaya meningkatkan nilai tambah bahan pangan melalui optimalisasi teknologi pengolahan untuk menghasilkan produk yang tetap bermutu tinggi dengan biaya yang tidak terlalu mahal sangat diperlukan, sehingga dapat terjangkau masyarakat umum. Penemuan jumlah/kadar yang optimal penggunaan baking powder sebagai bahan tambahan, untuk mengurangi penggunaan jumlah telur, untuk menghasilkan sponge cake yang 
berkualitas dan harga terjangkau perlu diuji cobakan melalui penelitian eksperimen ini. Penyusunan raancangan variasi kadar baking powder dan telur dalam formulasi cake dibutuhkan ketelitian, sehingga mendapatkan hasil sesuai harapan. Berdasarkan konsep dasar dan latar belakang yang telah diuraikan, secara eksplisit terdapat dua permasalahan pokok yang diupayakan pemecahannya dalam penelitian eksperimen ini, yaitu 1) Berapakah kadar/jumlah optimal penggunaan baking powder sebagai bahan tambahan, untuk mengurangi penggunaan jumlah telur dalam formulasi adonan sponge cake ? dan 2) Apa kendala-kendala dalam pelaksanaan penelitian ini?

Cake merupakan salah satu hidangan selingan yang memiliki rasa manis dan tekstur yang lembut, yang terdiri dari tepung, gula, telur, lemak dan bahan pengharum dengan teknik penyelesaiannya dengan cara dioven. Tiap bahan memiliki fungsi yang berbeda-beda untuk menghasilkan cake yang baik yakni 1) bahan pembentuk susunan cake meliputi tepung terigu, telur, susu ;2) bahan pengempuk cake meliputi gula, lemak, baking powder (Making Cake, 2005).

Tepung merupakan bahan utama dalam pembuatan cake. Tepung yang digunakan adalah tepung terigu yang memiliki protein sedang atau juga tepung terigu protein rendah. Telur merupakan salah satu produk peternakan unggas, yang memiliki kandungan gizi lengkap dan mudah dicerna. Dalam pengolahan pangan, telur memiliki fungsi misalnya sebagai pengemulsi, pemberi rasa, pengembang adonan, pembuih dan lain-lain. Susu merupakan bahan salah satu bahan cair yang memberikan nilai gizi. Gula berfungsi selain sebagai pemanis, gula memiliki fungsi khusus yaitu mematangkan susunan sel-sel cake serta mengempukkan susunan cake, memberi warna pada adonan (caramel), dan sebagai pengawet. Kekurangan gula menyebabkan cake keras dan tidak tahan lama, serta volume cake rendah dan pecah-pecah. Kelebihan gula menyebabkan cake cepat gosong tetapi didalamnya masih mentah. Lemak yang dimaksud adalah butter atau mentega yaitu lemak yang berasal dari susu hewan dan campuran air, margarin yaitu lemak yang berasal dari tumbuh-tumbuhan dicampur air, sedang shortening adalah lemak yang mengandung 100\% lemak. Lemak berfungsi memberi daya tahan kue, menambah nilai gizi, memberi aroma pada cake, mengempukkan, menimbulkan rasa gurih (Nova, 1992). Baking Powder adalah hasil reaksi dari asam dan sodium 
bikarbonat yang memakai atau tidak tepung sebagai bahan pengisi. Baking powder berfungsi sebagai pengempuk kue karena dalam proses pembakaran adonan dibuat terbuka dan berpori-pori lebih banyak sehingga hasil kue/cake mengembang dengan sempurna (Risa \& Marsiti, 2007).

Proses pembuatan cake memerlukan ketelitian dan ketrampilan dalam meramu bahan, sehingga menghasilkan cake yang baik. Metode yang tepat dalam pembuatan cake akan membantu meminimalisasi kesalahan yang terjadi selama proses. Dalam proses pembuatan cake yang terpenting adalah pengembangan dari cake tersebut, jika cake tidak mengembang dengan baik dan maksimal maka cake tersebut dikatakan gagal. Proses pengembangan cake mengalami 3 tahapan yaitu 1) Tahap Pengocokan. Pada tahap ini adonan diberi tekanan udara sehingga adonan akan mengembang dan ringan. Pengocokan menggunakan alat mixer; 2) Tahap Peragian. Dalam proses peragian, adonan mengalami pengembangan sehingga adonan bertambah besar dan ringan. Bahan untuk proses peragian adalah baking powder; 3) Tahap Pengovenan. Dalam proses pengovenan adonan menerima panas dari segala arah sehingga adonan mengalami pengembangan kembali sekaligus mengalami proses pematangan.

Suhu pembakaran untuk setiap jenis cake berbeda tergantung jenis, ukuran, jumlah unit dan formula cake. Semakin lengkap formula cake, maka suhu pembakarannya lebih rendah. Formula yang kurang lengkap dibakar dengan suhu lebih tinggi.

- Formula lengkap (rich formula) mengandung banyak telur dan lemak serta gas/aerasi diperoleh selama pengocokan.

- Formula kurang lengkap (lean formula) kandungan lemak dan telurnya diganti dengan cairan, sehingga ditambahkan baking powder untuk mengkonpensasi hilangnya sumber aerasi/gas (Risa \& Marsiti, 2007).

Lebih lanjut dinyatakan bahwa Aerasi adalah pengisian udara ke dalam adonan cake. Proses ini merupakan tulang punggung dari seluruh proses pembuatan cake. Aerasi merupakan pembukaan struktur crumb (tekstur cake). Dalam pembuatan cake, aerasi yang terjadi adalah: 
1) Aerasi secara kimiawi

- terjadi oleh adanya gas CO2 yang disebabkan adanya interaksi alkali dan asam karena panas dan lembab. Substansi ini disebut baking powder

- gas memenuhi sel udara yang ada pada struktur protein, dimana gas ini mengembang karena panasnya oven. Proses pengembangan ini menyebabkan peningkatan volume.

- Pengembangan volume dapat dipertahannkan karena adanya penggumpalan (koagulasi) protein.

2) Aerasi secara fisik dan mekanik

- udara ditangkap/dimasukkan ke dalam adonan dengan cara mengocok bahanbahan secara manual atau dengan mixer.

- Bahan yang dikocok dapat berupa lemak dan gula atau gula dan telur

3) Aerasi secara kombinasi

Dalam proses ini merupakan pengaturan keseimbangan dari formula:

- bila telur dan lemak dikurangi dan diganti dengan cairan seperti air/susu cair, maka ditambahkan baking powder

- baking powder ditambahkan untuk mengkompensasi hilangnya kemampuan aerasi secara fisik/mekanik

Penilaian cake merupakan suatu cara untuk menilai kualitas cake yang baik. Cake yang baik dapat dikategorikan apabila memenuhi syarat-syarat 1) Simetris, apabila semua sisi dari cake tersebut sama dan tidak memiliki bentuk; 2) Bloom (cerah), warna cake cerah; 3) Volume, cake yang baik bervolume sedang, sehingga susunan cake terlihat baik; 4) Susunan cake sempurna, tidak menggumpal, tidak kasar, permukaannya halus dan lembut; 5) Rasa manis; dan 6) Aroma berbau harum (Sedap Sekejap, 2000).

\section{METODE PENELITIAN}

Penelitian ini merupakan penelitian laboratorium (eksperimen) optimalisasi penggunaan bahan pembuatan sponge cake dengan perlakuan yang dirancang peneliti. Teknik pengulangan digunakan sebagai alternatif dari teknik sampling dan analisis data dilakukan secara deskriptif. Hal ini dilakukan karena karakteristik 
pembuatan sponge cake, melibatkan kue ukuran relatif besar (jumlah sampel besar tidak umum digunakan) dan para pembuat sponge cake biasanya cukup dengan dua sampai dengan tiga kali pengulangan untuk menguji coba resep. Variabel bebas penelitian sebagai perlakuan penelitian berupa kombinasi kadar telur, baking powder, dan lemak dalam resep pembuatan sponge cake. Sementara variabel terikat penelitian berupa tingkat kesimetrisan, kecerahan warna, volume, tekstur, rasa manis, dan aroma sponge cake.

Perlakuan penelitan berupa variasi kadar baking powder, dan telur yang digunakan sebagai pengganti kekurangan cairan akibat pengurangan jumlah telur, diganti dengan penambahan air secukupnya (karena sebagian dari air yang ditambahkan akan hilang atau mempengaruhi hasil cake). Rancangan perlakuan penelitian disajikan dalam Tabel 1. Untuk lebih menjamin ketelitian kuantitas bahan, semua diukur dengan menimbang. Masyarakat yang biasanya menggunakan satuan butir untuk telur, tidak akan sulit menggunakan satuan massa (timbangan). Satu telur ayam ras biasanya memiliki massa rata-rata 50-60 gram. Kadar telur, lemak, dan baking powder maksimum relatif terhadap tepung terigu yang direkomendasikan dalam pembuatan kue sponge cake adalah 100\%, 20\%, dan 8\% (Risa \& Marsiti, 2007).

Tabel 1. Rancangan Variasi Kadar Baking Powder dan Telur dalam Pembuatan Sponge Cake

\begin{tabular}{|l|l|l|l|l|l|l|l|l|l|l|}
\hline No & \multicolumn{2}{|l|}{$\begin{array}{l}\text { Kadar (\%) Bahan yang Ditam- Tampilan Parameter Kualitas Sponge Cake } \\
\text { bahkan Relatif Terhadap Telur * }\end{array}$} \\
\cline { 2 - 11 } & $\begin{array}{l}\text { Baking } \\
\text { Powder }\end{array}$ & $\begin{array}{l}\text { Kadar } \\
\text { Telur }\end{array}$ & Lemak & Air & $\begin{array}{l}\text { Sime- } \\
\text { tris }\end{array}$ & Warna & Volume & Tekstur & Rasa & Aroma \\
\hline 1 & 0 & 100 & 20 & 0 & & & & & & \\
\hline 2 & 1 & 90 & 20 & 9 & & & & & & \\
\hline 3 & 2 & 80 & 20 & 18 & & & & & & \\
\hline 4 & 3 & 70 & 20 & 34 & & & & & & \\
\hline 5 & 4 & 60 & 20 & 42 & & & & & & \\
\hline 6 & 5 & 50 & 20 & 42 & & & & & & \\
\hline 7 & 6 & 40 & 20 & 34 & & & & & & \\
\hline 8 & 7 & 30 & 20 & 26 & & & & & & \\
\hline 9 & 8 & 20 & 20 & 18 & & & & & & \\
\hline
\end{tabular}

Catatan : Masing-masing resep diulang tiga kali.

Kemungkinan pengaruh jumlah lemak, terutama sebagai bahan pengemulsi terhadap kualitas produk juga dikaji dengan memvariasi komposisi lemak yang ditambahkan 
terhadap resep di atas yang menghasilkan hasil terbaik. Perlakuan komposisi lemak meliputi tiga variasi (disajikan dalam Tabel 2).

Tabel 2. Perlakuan komposisi lemak pada tiga variasi

\begin{tabular}{|c|l|l|l|l|l|l|l|l|}
\hline No & \multicolumn{2}{|l|}{$\begin{array}{l}\text { Kadar (\%) Bahan yang Ditam-bahkan } \\
\text { Relatif Terhadap Telur * }\end{array}$} & \multicolumn{3}{l|}{ Tampilan Parameter Kualitas Sponge Caker } \\
\cline { 2 - 8 } & $\begin{array}{l}\text { Baking Powder } \\
\text { + Kadar Telur + Air }\end{array}$ & Lemak & $\begin{array}{l}\text { Sime- } \\
\text { tris }\end{array}$ & Warna & Volume & Tekstur & Rasa & Aroma \\
\hline 1 & $\begin{array}{l}\text { Komposisi baking powder dan } \\
\text { telur terbaik }\end{array}$ & 30 & & & & & & \\
\hline 3 & & 20 & & & & & & \\
\cline { 3 - 8 } & & 10 & & & & & & \\
\hline
\end{tabular}

Catatan: masing-masing resep diulang tiga kali

Penelitian ini melibatkan penimbangan bahan-bahan dan pengamatan kualitas produk. Massa bahan-bahan kue sesuai dengan rancangan perlakuan, ditimbang menggunakan timbangan dengan ketelitian dua angka di belakang koma (centi gram). Penilaian kualitas produk menggunakan rubrik penilaian dalam Tabel 3.

Tabel 3. Rubrik Penilaian Kualitas Sponge Cake

\begin{tabular}{|c|c|c|c|c|}
\hline \multirow[t]{2}{*}{ No } & \multirow{2}{*}{$\begin{array}{l}\text { Aspek } \\
\text { Kualitas }\end{array}$} & \multicolumn{3}{|l|}{ Gradasi Kualitas } \\
\hline & & Baik & Sedang & Kurang \\
\hline 1 & Simetris & $\begin{array}{l}\text { Semua sisi cake sama } \\
\text { atau rata }\end{array}$ & $\begin{array}{l}\text { Tengah-tengah tinggi dan } \\
\text { tidak rata }\end{array}$ & $\begin{array}{l}\text { Sisi cake rendah dan } \\
\text { cekung ditengah }\end{array}$ \\
\hline 2 & Warna & Cerah & Kurang cerah & Pucat \\
\hline 3 & Volume & Volume sedang & Volume kecil & Tidak mengembang \\
\hline 4 & Tekstur & Lembut dan halus & Agak kasar/kasar & $\begin{array}{l}\text { Bergumpal-gumpal atau } \\
\text { mudah hancur }\end{array}$ \\
\hline 5 & Rasa & Manis & Kurang Manis & Tidak manis atau pahit \\
\hline 6 & Aroma & Harum & Kurang harum & Tidak beraroma \\
\hline
\end{tabular}

Data hasil penelitian kualitas sponge cake yang meliputi kesimetrisan, kecerahan warna, volume, tekstur, rasa manis, dan aroma dianalisis dan disajikan secara deskriptif. Tingkat kualitas kue ditentukan berdasarkan kombinasi dari keenam penilaian aspek di atas.

\section{HASIL PENELITIAN}

Rancangan variasi kadar baking powder dan telur dalam pembuatan sponge cake sedikit diubah dari rancangan awal, karena ketika rancangan variasi awal diujicoba hasil yang didapatkan tidak maksimal dan belum memenuhi standar kualitas sponge cake. Perubahan rancangan variasi kadar baking powder dan telur dalam pembuatan sponge cake tetap mengacu pada komposisi bahan yang 
direkomendasi dalam kajian pustaka yaitu kadar telur, lemak, dan baking powder maksimum relatif terhadap tepung terigu adalah 100\%, 20\%, dan 8\%. Kombinasi pertama adalah kandungan baking powder membesar dan kandungan telur mengecil, tetapi kandungan lemak tetap. Kombinasi kedua adalah kombinasi telur dan baking powder tertentu (paling efektif) merupakan hasil terbaik dari kombinasi pertama, tetapi kandungan lemak bervariasi.

Resep sponge cake secara umum digunakan sebagai acuan dalam menetapkan rancangan variasi kadar baking powder, telur dan lemak dalam satuan gram. Secara umum bahan pembuatan sponge cake meliputi tepung terigu, telur, gula dan lemak. Air (cairan) digunakan sebagai bahan pengganti telur dengan menambahkan baking powder untuk mengkonpensasi hilangnya sumber aerasi/gas. Data hasil penelitian eksplorasi meliputi produk sponge cake yang tidak menggunakan baking powder (hanya dilakukan sekali) dan produk sponge cake yang menggunakan baking powder sebanyak sembilan kombinasi dan diuji coba sebanyak tiga kali (masing-masing kombinasi) dan tingkat kualitas sponge cake berdasarkan sembilan variasi kadar bahan disajikan dalam Tabel 4 .

Tabel 4. Hasil Rancangan Variasi Kadar Baking Powder dan Telur dalam Pembuatan Sponge Cake

\begin{tabular}{|c|c|c|c|c|c|l|l|l|l|l|}
\hline No & \multicolumn{7}{|l|}{$\begin{array}{l}\text { Kadar (gr) } \\
\text { bahkan Relatif Terhadap Telur * }\end{array}$} & \multicolumn{7}{l|}{ Tampilan Parameter Kualitas Sponge Cake } \\
\cline { 2 - 13 } & $\begin{array}{c}\text { Baking } \\
\text { Powder }\end{array}$ & $\begin{array}{c}\text { Kadar } \\
\text { Telur }\end{array}$ & Lemak & Air & $\begin{array}{c}\text { Sime- } \\
\text { tris }\end{array}$ & Warna & Volume & Tekstur & Rasa & Aroma \\
\hline 1 & 0 & 180 & 75 & 0 & baik & baik & baik & baik & baik & baik \\
\hline 2 & 6 & 100 & 75 & 0 & baik & baik & baik & baik & baik & baik \\
\hline 3 & 8 & 100 & 75 & 0 & baik & sedang & baik & baik & baik & baik \\
\hline 4 & 10 & 80 & 75 & 34 & kurang & sedang & kurang & sedang & kurang & kurang \\
\hline 5 & 8 & 80 & 75 & 18 & kurang & sedang & kurang & sedang & kurang & kurang \\
\hline 6 & 6 & 80 & 75 & 18 & kurang & sedang & kurang & kurang & kurang & kurang \\
\hline 7 & 4 & 80 & 75 & 16 & baik & baik & baik & sedang & baik & baik \\
\hline 8 & 2 & 80 & 75 & 16 & baik & baik & baik & baik & baik & baik \\
\hline 9 & 12 & 60 & 75 & 42 & kurang & sedang & kurang & kurang & kurang & kurang \\
\hline 10 & 16 & 20 & 75 & 42 & kurang & kurang & kurang & kurang & kurang & kurang \\
\hline
\end{tabular}

Produk sponge cake yang dibuat tanpa menggunakan baking powder (resep dasar) mendapatkan hasil yang maksimal (terbaik) yaitu simetris (semua sisi sama, warna cerah, tekstur lembut, rasa manis, dan aroma harum dengan pemakaian jumlah telur yang maksimal pula. Adapun perbandingan bahan (resep dasar) yang digunakan 
tepung terigu : gula pasir : margarin : telur adalah $100: 100: 75: 180$ dalam satuan gram. Hasil pembuatannya disajikan pada gambar 1. di bawah ini.
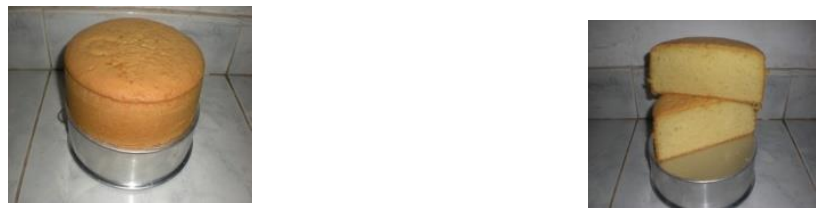

Gambar 1. Sponge cake tanpa baking powder (resep dasar)

Resep dasar sponge cake digunakan sebagai acuan dalam membuat variasi kadar baking powder dan telur. Dari sembilan variasi yang dirancang mendapatkan hasil sponge cake yang dapat dikategorikan baik, sedang dan kurang. Hal ini dapat dilihat dari hasil Rancangan Variasi Kadar Baking Powder dan Telur dalam Pembuatan Sponge Cake pada tabel 5.1. Hasil penelitian menunjukkan bahwa produk sponge cake yang menggunakan baking powder menghasilkan kualitas cake yang bervariasi tergantung formulasi bahan yang digunakan. Kualitas sponge cake kategori baik dengan penambahan baking powder dihasilkan dari rancangan variasi kadar Baking Powder dan Telur yaitu 1) formulasi baking powder 6 gram, telur 100 gram, dan tanpa ditambahkan air , 2) formulasi baking powder 2 gram, telur 80 gram, dan air 16 gram. Kedua hasil eksperimen sponge cake ini memenuhi semua kriteria cake yang baik yaitu cake simetris (semua sisi sama dan rata), warna cake cerah, volume sedang, tekstur lembut, rasa manis (tidak pahit), dan aroma cake harum. Hasil eksperimen disajikan pada gambar 2. dan gambar 3. di bawah ini
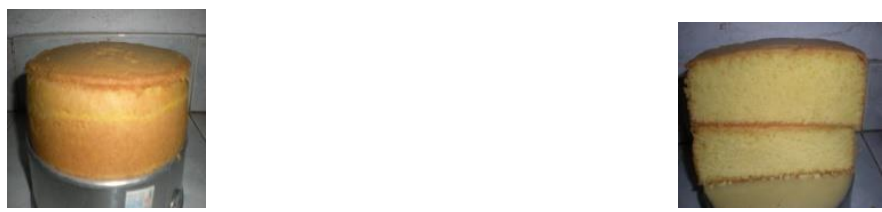

Gambar 2. Hasil Rancangan Variasi Kadar Baking Powder dan Telur (6 : 100 gr)
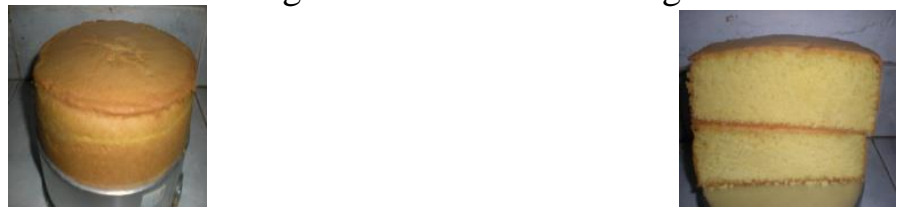

Gambar 3. Hasil Rancangan Variasi Kadar Baking Powder dan Telur (2 : 80 gram) Kualitas sponge cake kategori sedang dicapai pada rancangan variasi kadar Baking Powder dan Telur 1) formulasi baking powder 8 gram, telur 100 gram, dan tanpa 
ditambahkan air dan 2) formulasi baking powder 4 gram, telur 80 gram, dan air 16 gram. Sponge cake dengan formulasi di atas dikategorikan sedang, karena walaupun secara umum cake yang dihasilkan baik namun masih terdapat beberapa kekurangan yang terjadi, seperti pada formulasi pertama warna cake kurang cerah. Pada formulasi kedua tekstur cake agak berongga (tekstur kurang rapat).
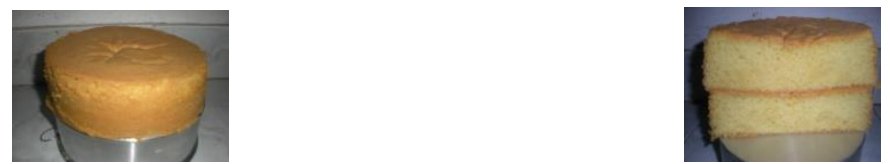

Gambar 4. Hasil Rancangan Variasi Kadar Baking Powder dan Telur (8 : 100 gr)
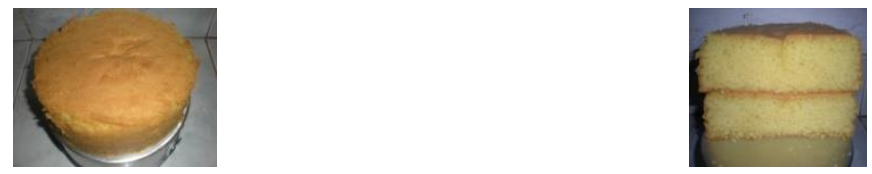

Gambar 5. Hasil Rancangan Variasi Kadar Baking Powder dan Telur (4 : 80 gr) Sedangkan sponge cake kategori kurang dihasilkan dari rancangan variasi kadar Baking Powder dan Telur dengan formulasi 1) 10 gram baking powder, telur 80 gram, dan air 18 gram, 2) 8 gram baking powder, telur 80 gram, dan air 18 gram, 3) 6 gram baking powder, telur 80 gram, dan air 18 gram, 4) 12 gram baking powder, telur 60 gram, dan air 34 gram, 5) 16 gram baking powder, telur 20 gram, dan air 42 gram. Kelima hasil rancangan sponge cake ini dikategorikan kurang baik karena sisi cake rendah dan cekung di tengah, warna pucat, cake bergumpal-gumpal atau mudah hancur, rasa cake cenderung pahit dan cake tidak beraroma.
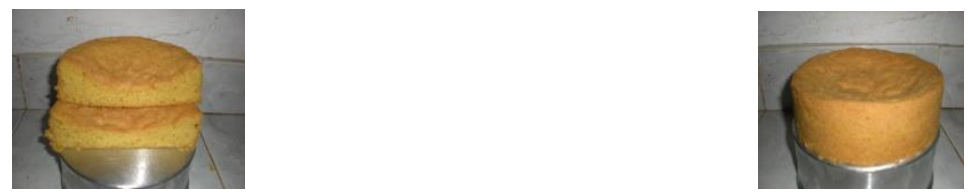

Gambar 6. Hasil Rancangan Variasi Kadar Baking Powder dan Telur (4 gr : 80 gr)
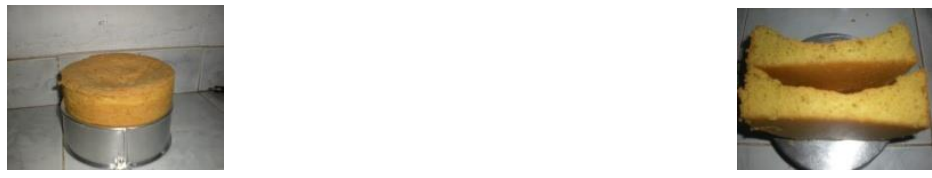

Gambar 7. Hasil Rancangan Variasi Kadar Baking Powder dan Telur (8 : 80 gr)
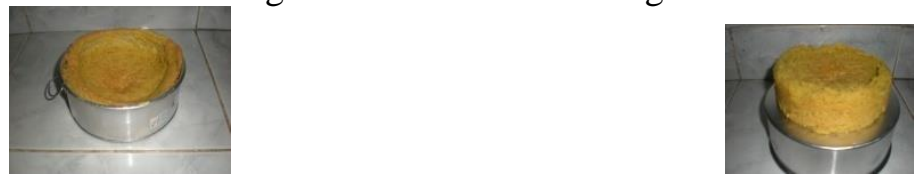
Gambar 8. Hasil Rancangan Variasi Kadar Baking Powder dan Telur (10 : 80 gr)
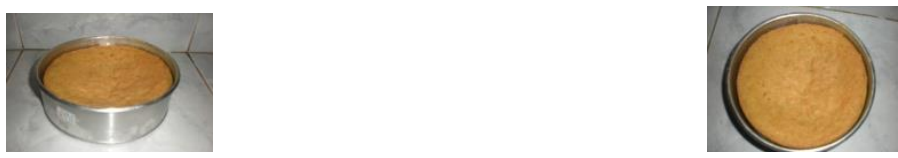

Gambar 9. Hasil Rancangan Variasi Kadar Baking Powder dan Telur (12 : 60 gr)
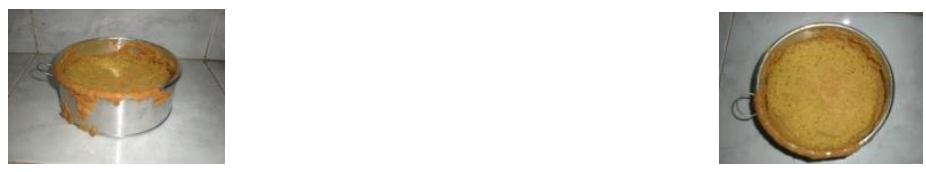

Gambar 10. Hasil Rancangan Variasi Kadar Baking Powder dan Telur (16 : 20 gr)

Kombinasi kedua adalah kombinasi telur dan baking powder yang menghasilkan cake kategori baik atau merupakan hasil terbaik dari kombinasi pertama, dengan kandungan lemak yang divariasikan. Hal ini bertujuan untuk mengetahui pengaruh lemak sebagai bahan pengemulsi terhadap kualitas produk sponge cake. Perlakuan komposisi lemak meliputi tiga variasi yang menghasilkan sponge cake dengan tampilan parameter sebagai berikut :

\begin{tabular}{|c|c|c|c|c|c|c|c|c|}
\hline \multirow[t]{2}{*}{$\mathrm{No}$} & \multicolumn{2}{|c|}{$\begin{array}{l}\text { Kadar (\%) Bahan yang Ditam-bahkan } \\
\text { Relatif Terhadap Telur * }\end{array}$} & \multicolumn{6}{|c|}{ Tampilan Parameter Kualitas Sponge Caker } \\
\hline & $\begin{array}{l}\text { Baking Powder } \\
+ \text { Kadar Telur }+ \text { Air }\end{array}$ & Lemak & $\begin{array}{l}\text { Sime- } \\
\text { tris }\end{array}$ & Warna & Volume & Tekstur & Rasa & Aroma \\
\hline 1 & \multirow{3}{*}{$\begin{array}{l}\text { Komposisi baking powder } \\
\text { dan telur terbaik }\end{array}$} & 30 & baik & baik & baik & baik & baik & baik \\
\hline 2 & & 20 & baik & baik & baik & baik & baik & baik \\
\hline 3 & & 10 & baik & sedang & baik & sedang & baik & sedang \\
\hline
\end{tabular}

Hasil cake dengan kadar lemak 30\% menghasilkan cake lebih basah karena penggunaan lemak yang banyak. Warna cake lebih kuning dan tekstur lembut.
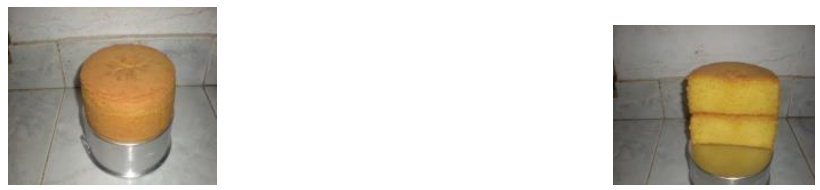

Gambar 11. Hasil Rancangan Variasi Kadar Lemak sebanyak 30\%

Sedangkan sponge cake dengan variasi lemak sebanyak $10 \%$ teksturnya lebih padat dari formulasi lemak $20 \%$ dan lebih berongga. Warna cake lebih muda karena lemak juga memberi efek pewarnaan pada cake. 

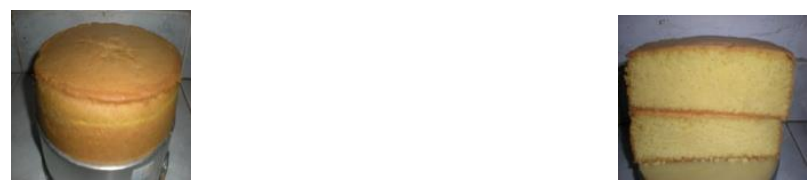

Gambar 12. Hasil Rancangan Variasi Kadar Lemak sebanyak 10\%

Selain rancangan kombinasi pertama dan kedua, ujicoba dilakukan pada resep (hasil kombinasi pertama) tanpa menggunakan lemak. Pengembangan cake hanya dari penggunaan telur dan tidak mengembang maksimal (cake bantat), warna cake pucat, rasa manis, tekstur padat dan aroma cake kurang. Pada bagian dasar cake cekung ditengah-tengah.
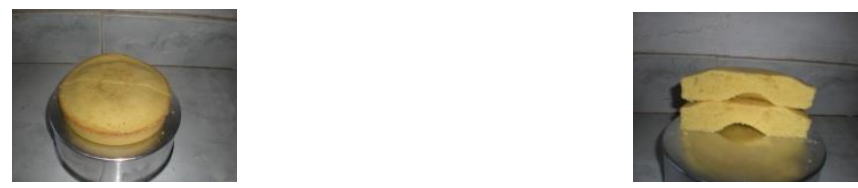

Gambar 12. Hasil Rancangan Variasi Tanpa Lemak

\section{PEMBAHASAN}

Berdasarkan data hasil temuan di atas, ditetapkan formulasi optimal penggunaan baking powder sebagai pengganti jumlah telur berdasarkan hasil rancangan variasi kadar baking powder dan telur yang telah disempurnakan. Kadar baking powder optimal dalam pembuatan sponge cake untuk menghasilkan kualitas cake yang baik (dua terbaik dari sembilan rancngan variasi kadar baking powder dan telur) adalah 1) formulasi baking powder 6 gram, telur 100, dan tanpa ditambahkan air, dan 2) formulasi baking powder 2 gram, telur 80 gram, dan air 16 gram.

Data hasil penelitian komparasi, berupa sembilan rancangan variasi kadar baking powder dan telur dengan memperhatikan aspek kualitas yang terdiri dari kesimetrisan, warna, tekstur, rasa, aroma, dan volume. Sedangkan gradasi kualitas meliputi baik, sedang dan kurang. Resep dasar sponge cake digunakan sebagai landasan untuk membuat rancangan variasi kadar baking powder dan telur. Adonan sponge cake dengan kombinasi bahan yang tepat menghasilkan cake yang berkualitas baik Sebaliknya komposisi resep yang kurang tepat dapat menyebabkan kesalahan utama dalam pembuatan cake (Sedap Sekejap, 2000). Penambahan baking powder dalam kadar yang tepat (optimal) menghasilkan sponge cake dengan pori- 
pori baik (rapat), warna cake cerah, tekstur lembut, rasa baik, volume cake bertambah pada saat dioven dan volume tetap, hingga cake matang. Sebaliknya penggunaan baking powder yang berlebihan membuat cake cepat mengembang pada saat dioven, namun volume akan turun ketika cake matang. Penambahan baking powder yang tidak sesuai (lebih) menghasilkan pori-pori cake lebih berongga (kurang rapat), aroma cake kurang atau tidak beraroma (kurang harum), pada bagian tengah cake membentuk cekungan, cake beremah (mudah hancur), dan rasa agak pahit/pahit.

Penelitian ini menemukan terdapat pengaruh antara penggunaan baking powder dalam kadar tertentu sebagai pengganti telur terhadap cake yang dihasilkan. Hal ini bukan berarti bahwa kualitas cake hanya ditentukan oleh seberapa banyak baking powder yang digunakan sebagai pengganti telur, tetapi faktor lain yang juga memiliki pengaruh terhadap kualitas cake yang dihasilkan seperti bahan-bahan yang digunakan, juga merupakan hal penting yang harus diperhatikan misalnya penggunaan tepung dan lemak yang tepat dan berkualitas, kualitas telur, proses pembuatan adonan (pengocokan), proses pengovenan (suhu yang tepat) dan lamanya proses pematangan. Semakin lengkap formula cake, maka suhu pembakarannya lebih rendah, sedangkan cake dengan formulasi kurang lengkap memerlukan suhu pembakaran yang lebih tinggi (Risa \& Marsiti, 2007). Bila dilihat dari formulasi adonan cake, proses pengembangan sponge cake ditandai dengan adanya gelembung-gelembung halus dan kekentalan adonan cukup (Nova, 1992).

Kualitas cake dilihat dari tingkat kesimetrisannya, terlihat dari permukaan cake yang dihasilkan yaitu tingginya simetris (sama) dan rata. Warna cake adalah kuning cerah atau kuning keemasan, yang dihasilkan dari warna kuning telur dan juga pengaruh lemak yang digunakan yaitu mentega kuning. Tekstur cake ditunjukkan dari halus/lembut atau kasarnya permukaan cake yang dihasilkan. Tekstur cake yang baik bila pori-porinya rapat dan halus. Volume cake meningkat selama proses pematangan (pengovenan) ditandai dengan naiknya volume adonan hingga batas tertentu dan tetap hingga cake matang (dikeluarkan dari oven). Rasa cake pada umumnya manis, dengan penambahan gula dalam adonan. Aroma cake pada 
umumnya harum, baunya tercium ketika cake memasuki tahap menuju matang. Aroma cake sering digunakan sebagai tanda bahwa cake telah matang.

Sumber utama cairan cake adalah telur. Jika telur dan lemak yang digunakan sedikit atau dikurangi maka fungsi cairan bisa diganti dengan air, santan atau susu (Risa \& Marsiti, 2007). Dalam penelitian ini cairan pengganti telur digunakan air biasa, dan berfungsi untuk menjaga kekentalan adonan. Untuk mengkompensasi hilangnya kemampuan aerasi secara fisik (pengisian udara ke dalam adonan cake), maka ditambahkan baking powder dalam adonan, sebab aerasi membentuk struktur crumb (tekstur cake). Penggunaan jumlah air, tergantung tingkat kepadatan adonan yang dihasilkan dari rancangan variasi kadar baking powder dan telur, namun penggunaanya tetap diukur dalam satuan gram untuk mendapatkan formulasi adonan yang tetap.

Dari segi ekonomi yang meliputi biaya produksi (unit cost), cake dengan penambahan baking powder sebagai pengganti jumlah telur yang dikurangi, memerlukan biaya lebih murah dalam proses pembuatannya, dibanding dengan cake yang tanpa baking powder, sebab harga baking powder cenderung lebih murah daripada harga telur yang saat ini terus meningkat. Namun bila dilihat dari segi nilai gizi, tentu saja cake yang formulasinya tidak menggunakan baking powder lebih bernilai gizi, sebab telur merupakan salah satu sumber gizi protein dan lemak.

Kendala dalam penelitian hampir tidak ada, walaupun ada hanya kendala teknis yang segera dapat peneliti atasi misalnya, dalam proses penimbangan dalam jumlah sedikit cukup sulit dilakukan, meskipun timbangan yang digunakan berupa timbangan elektrik yang tingkat akurasinya cukup tinggi.

\section{PENUTUP}

Berdasarkan hasil penelitian dan pembahasan hasil eksperimen pembuatan sponge cake dapat diambil beberapa simpulan sebagai berikut. Hasil kombinasi pertama kualitas sponge cake kategori baik dengan penambahan baking powder dihasilkan dari rancangan variasi kadar Baking Powder dan Telur yaitu 1) formulasi baking powder 6 gram, telur 100 gram, dan tanpa ditambahkan air , 2) formulasi baking powder 2 gram, telur 80 gram, dan air 16 gram. Kualitas sponge cake 
kategori sedang dicapai pada rancangan variasi kadar Baking Powder dan Telur 1) formulasi baking powder 8 gram, telur 100 gram, dan tanpa ditambahkan air dan 2) formulasi baking powder 4 gram, telur 80 gram, dan air 16 gram. Sedangkan sponge cake kategori kurang dihasilkan dari rancangan variasi kadar Baking Powder dan Telur dengan formulasi 1) 10 gram baking powder, telur 80 gram, dan air 18 gram, 2) 8 gram baking powder, telur 80 gram, dan air 18 gram, 3) 6 gram baking powder, telur 80 gram, dan air 18 gram, 4) 12 gram baking powder, telur 60 gram, dan air 34 gram, 5) 16 gram baking powder, telur 20 gram, dan air 42 gram.

Hasil kombinasi kedua penggunaan lemak sebanyak 30\%, 20\%, dan $10 \%$ sama-sama menghasilkan sponge cake dengan kualitas baik. Walaupun penelitian ini berhasil menemukan kadar optimal baking powder untuk menghasikan cake dengan kualitas baik, perbaikan rasa dan aroma cake masih dapat diperbaiki dengan penggunaan bahan-bahan pengaroma atau penggunaan cairan susu, sari buah dan santan.

\section{DAFTAR PUSTAKA}

Anon. 1992. Mencegah Kegagalan Pembuatan Cake. Jakarta: Majalah Nova

Anon. 2000. Rahasia Cake Anti Gagal. Jakarta: Majalah Sedap Sekejap

Anon. 2005. Modul “Making Cake”. Surabaya: Bogasari Baking Center

Ariani, Risa Panti dan Marsiti, Cok. Istri R. 2007. Modul "Pelatihan Ketrampilan Boga". Singaraja: Undiksha 